\title{
【論【文】
}

\section{ビデオ撮影による不燃・粗大ごみの質・量の計測と 住居形態別ごみ発生特性}

\author{
松藤敏彦*・田中信 寿*・松尾孝之*・小針昌則**・神山桂一*
}

【要旨】適正なごみ処理を選択，実施するには，ごみ量，ごみ質を把握することが重要である。ごみ量 については収集量データを用いる方法があるが，ごみ質は組成分析調査によるしかなかった。筆者らは， 不燃・粗大ごみは目視でかなりの部分が判別できることに注目して, ビデオ撮影による調査法を提案し, 対象地域を定めて一年間調査を継続した。

ごみの種類は非常に多いため, それを $6 \supset$ 項月に大分類した。調査によって得られる個数データか ら重量を推定するため, 組成別の重量を測定し, 収集車一台分の重量推定誤差は $10 \%$ 以内と良好で あった。降雨により $10 \%$ 程度重量が増加している。次に, 住居形態の異なるステーション群で, 大分 類項目別の排出個数の变動を調へ，春先，9月，12月の増大が認められた。これらは季節の変わり目 の清掃行動によると考えられるが，住居形態により増大の程度，時期が異なっている。

キーワード：ビデオ撮影調査，不燃・粗大ごみ，排出特性，季節変動，住居形態

\section{1. はじめに}

近年, ごみ問題が次第に深刻さを増している中で, 状 況に合わせた処理プロセスを選択し適正な処理を行うた め,ごみの質（組成）および量を把握することがますま す重要になってきている。ところが，ごみの質と量はど ちらあ発生場所によってさまざまに異なり，さらに時間 （季節）によっても変化する。そのため, ごみ質，ごみ 量に関する調查・研究を行なう際には, こうした空間的, 時間的分布を念頭におくことが必要である。

筆者らは, 従前より都市ごみを対象として研究を進め ているが，まず，ごみ量について，行政区あるいは都市 レベルでの日収集量をデータとし, 時間的な変動を解析 した。これにより，季節変化 ${ }^{1)}$, 日変化パターン2)を明 らかにできたが，地域的な分布を知るにはデー夕単位を あっと小さく取る必要がある。そこで, 対象を一台の収 集車の担当区域（収集ブロックと呼んでいる）とし，そ の収集量データを用いて事業系ごみの混入によるごみ量 の増大を明らかにしだ)。さらに，住居形態別での発生

原稿受付 1990.9.12

* 北海道大学工学部衛生工学科

** 玩在, 日立製作所
量の季節変動パターンを知るため, ごみステーション単 位での写真撮影という, ごみ量測定の簡便法を提案し, 調査む試みている ${ }^{4.5) 。}$

一方,ごみ質については, 収集量データのような好都 合なデー夕はなく，組成分析を行なうしか方法がない。 時間的，空間的な分布を見るには，その一方を固定した 調查が必要であるが（上述のごみ量に関する研究では場 所を固定している), 組成分析を実施するには相当な労 力を要し，場所的な差を見るため同一日に多くの対象地 域で調查することも，また，時間的な変化を知るため特 定地域の調査を継続的に行うことも，非常に困難である。 現実に, 従来の調查は, 複数地域の組成の違いを異なっ た月の調査により議論したり, 年に $3 \sim 4$ 回の調查で特 定地域の季節変動を論じていたりするものがほとんどで ある。

筆者らが調査の対象としている札幌市では, 家庭系の ごみを可燃ごみと不燃・粗大ごみ（以下では，市で用い ている名称に従って「分別ごみ」と呼ぶ）の 2 分別で収 集している。可燃ごみはポリごみ垡などに人れて排出さ れ，その内容については組成分析によらなければ知るこ とはできない。しかし，分別ごみ（特に粗大ごみ）は袋 などに入れずそのままの形で排出されるものが多いため, 目視で内容の判別ができる。そこで, 迅速かつ簡便なご 
み質, ごみ量の調査法として，ビデオ撮影を考えた。本 論文では, ビデオ調查法の詳細とその有効性について述 へ，調査地域を定めて一年間継続した調査の結果につい て報告する。

\section{2. 調查対象地域およひ調查方法}

\section{1 調查対象地域}

調查対象としたのは, 札幌市北区内の約 0.17 平方キ ロメートル $(480 \mathrm{~m} \times 350 \mathrm{~m})$ の地区で，一户建て住宅， アパート, 集合住宅, 商店・事業所が混在しており, 区 役所, 警察署, 消防署, 小学校, 多目的ホールがある北 区の中心部である。地域の大きさは, 一台の収集車が一 回に収集できる範囲より決定した。住民基本台帳による 当該地域における世帯数は 1,158, 人口は 2,089 人（昭 和 63 年 10 月現在）である。地域内には 51 のごみス テーションがあるが, 警察署そばのステーションには ロッカー, 金庫, 事務机, コピー機などのほか, 常時 $20 \sim 40$ 個ものポリごみ袋（そのいくつかは清涼飲料の 空き缶）が排出されており, それらは家庭由来のものと は考え難い。このステーションには, 警察署に隣接する 航空管制部独身絭加と思われるごみも排出されている が, 前者の重量に占める割合はかなり高い。そこで, 中 心通りに面し, 排出がまれにしかなく, しかも段ボール 箱など, 事業活動に伴うごみのみである 3 つのステー ションと共に, 調査地域内の合計ごみ量を算出するとき には除外する。したがって, 以ドで言う調査地域合計ご み量は, 47 のステーションの合計である。なお，区役 所, 消防署, 多目的ホール, 小学校からのごみの排出は 認められず，委託業者により収集されていると思われる。

調査は昭和 63 年 (1988 年) 3 月から平成元年 (1989 年） 5 月まで行なったが, 昭和 63 年 6 月より収集頻度 が従来の月 2 回から週 1 回に变更になった。そのため, 本論文では, 頻度変更以降の一年間の調査デー夕に基づ いて考察を進める。調查地域の収集日は金曜日であるが (変更前は第 2 , 第 4 金曜日), この一年間, 収集業務は 毎週休みなく行なわれ, 調査む10月 7 日, 12 月 9 日, 5 月 5 日, 5 月 26 日の 4 回を除いて毎週実施した。ま た, 頻度変更に伴って各ステーションでの 1 回の排出量
が滅少し, 収集車一台の一日あたり収集範井が広くなっ たため, 調査地域を14 ステーション分広げた。しかし, この追加地域で調查期間中, 古い集合住宅の取り壊し, 新たな 5 階建て住宅の建設があり, 調查は継続したが, 以トで「調查地域」と咅うときにはこの追加地域を含め ていない。

\section{2 調全方法}

調查の方法は以下の通りである。

まず，ごみステーションの位置を記入した地図を作成 し, 収集経路を確認しておく。調査日に, 収集を開始す るステーションで待機し, 分別ごみ収集車 (パッカー 車）の後を別の本で追跡するが, 特に調查のための配慮 を依頼せず, 通常どおりに収集作業を行ってもらう。調 查は 2 人一組で, 一人が運転を, 他の一人が撮影を担当 する。ビデオカメラにはズーム機能があるので, ごみの 飛散も考慮し, 収集車から $5 \sim 10 \mathrm{~m}$ うしろに車を止め て撮影した。撮影では, ごみステーションで作業者がご みをとり, 収集車に投入するまでの作業の全体が写るよ うにし（ごみが写るチャンスを増すため），ビデオ再生 時にごみ一個ずつの認識が容易になるようにした。また， 画像のみからでは種類の識別が難しいことも少なくない ので, 撮影時にごみの内容を読み上げ, 音声による記録 あ行なった。カメラは助手席に三脚で阁定するが、ス テーション位㯰, 交通の状況によっては車から降りて撮 影しなければならないことがある。そのため, 充電式の バッテリーパックを電源として用いる方がよい。撮影す るのは積み込み作業のみであるが, 一回の調査での記録 時間は, ほとんどが 1 時間以内であった。

調査終了後, 記憶の鮮明なうちにビデオテープを再生 し, ステーションの通し番号と共にごみの種類, 個数を コンピュータファイルに書き込み, 数量データを作成し た。1 回の調查デー夕をファイル化するのに要した時間 は, デー夕整理用のプログラムを用意することで, 2 時 間以下とできた。ごみ組成名は調查を経るにつれて増え， 最終的には 213 個となり, それを 6 種類の項目に大分類 した。Table 1 に大分類を, Table 2 に大分類項目別 の全ごみ組成名，および各組成の重量（設定方法につい ては後述), 調査対象地域における一年間の排出個数を

Table 1 Categories of waste items

\begin{tabular}{|c|c|c|c|c|}
\hline \multicolumn{4}{|c|}{ 大分類項目 } & 内 \\
\hline 袋 & - & 箱 & 類 & ポリごみ袋・スーパーの買物袋・段ボール箱・紙袋など \\
\hline 家 & & 電 & 類 & 照明器具・テレビ・炊飯器・掃除機など \\
\hline 家 & & 具 & 類 & カーペット・たんす・テーブル・机・椅子など \\
\hline 自 & 転 & 車 & 類 & タイヤ・自転車・三輪車・ベビーカーなど \\
\hline ₹ & & 他 ( & & 家の中にあるあの（かばん・おあちゃ・なべなど） \\
\hline$\xi$ & の & 他 & & 家の外にあるあの（庭木・一斗缶・ガラス・物千しなど） \\
\hline
\end{tabular}




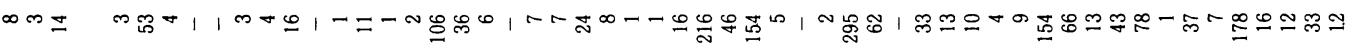

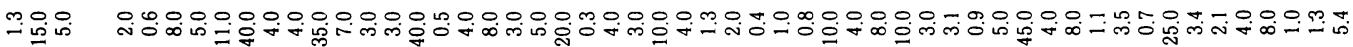

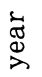

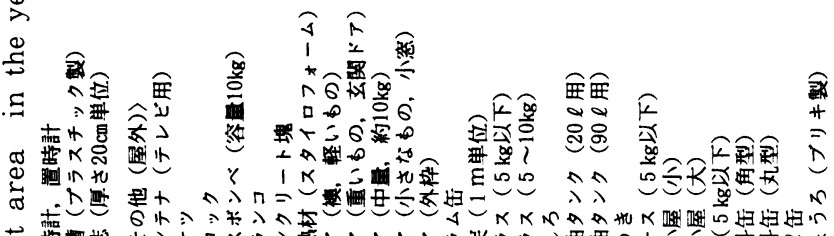

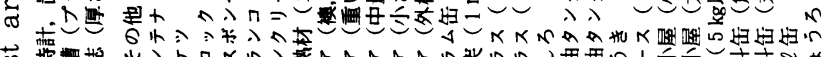

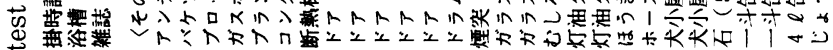

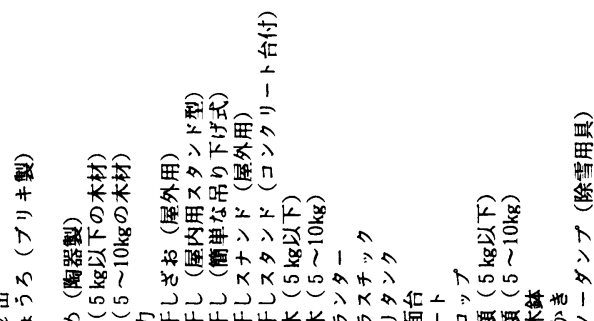

$\frac{\frac{1}{3}}{3}$

$\stackrel{\text { I }}{ \pm}$ .

D
$\mathscr{D}$
0
0
.0
.0



至

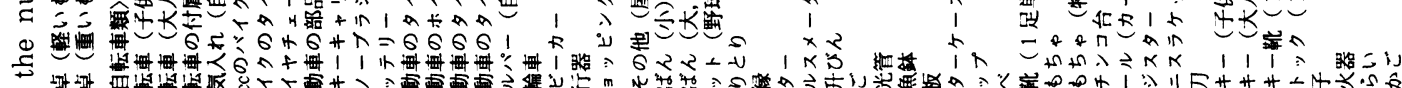
它 ๘ర

ఫ్రై

¿ี

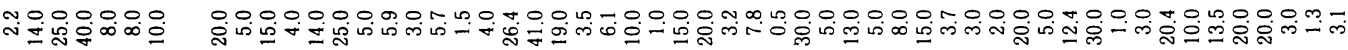

$\frac{3}{\sqrt{6}}$

要

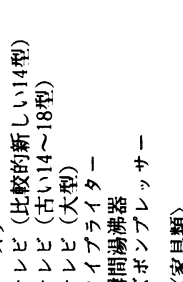

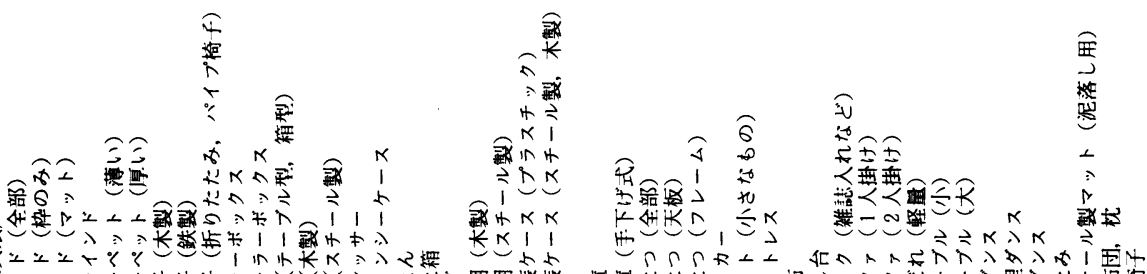

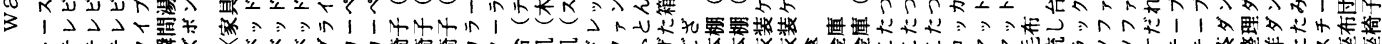

(1)

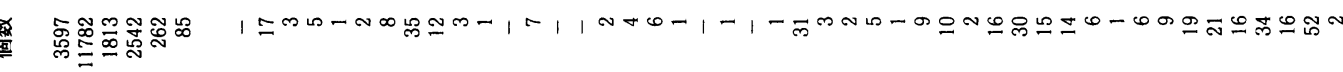

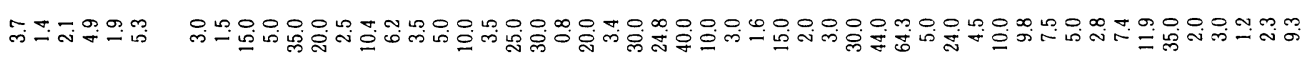

$\frac{0}{0}$

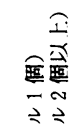

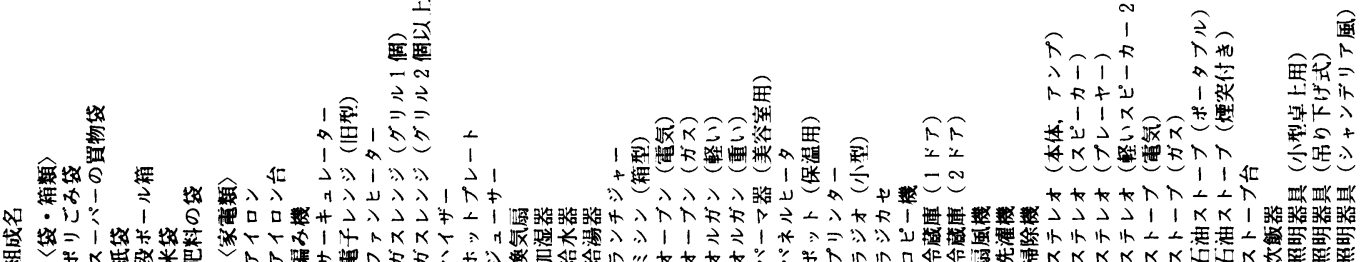


示す。なお, Table 1 中, その他（层内）, その他（屋 外）を，本文中ではそれぞれ屋内ごみ，屋外ごみと呼ぶ ことにする。

同一種類のものであっても, 冷蔵䡍, テレビ, ストー ブ,カーペットなどのように重量に大きな幅のあるあの が多くある。それらは，さらに項目を細分化した。びん， 蛍光管など小さいものは袋や箱に入っていて外見からは わからないことも多いと思われ, Table 2 の排出個数 は, いわゆる大型ごみのそれとは同一に見ることができ ない。また, Table 2 中, 個数がゼ口（'-で示され ている）のあのがあるが, それらは対象地域外あるいは 対象期間外に排出されていたものである。

\section{3. 調查対象地域内の分別ごみ質の季節変動}

Table 2 に示すように，排出される分別ごみの種類 は非常に多く，一年間の排出パターンを検討しうるだけ の排出個数がない項目む数多くある。また， Fig. 1 に 大分類項目のうち袋・箱類, 家具類について, 調査日ご との対象地域内合計排出個数を示すが, 日単位の変動が 大きく（外的要因による変動なのか, あるいは単に確率 的なばらつきなのかは，まだわからない），年間の変動 を読み取りにくい。(欠測日は線で結んでいない。）そこ で, 以下では排出ごみの種類は大分類項目でまとめ, さ らに月ごとの平均をとって表すことにする。ごみ組成の

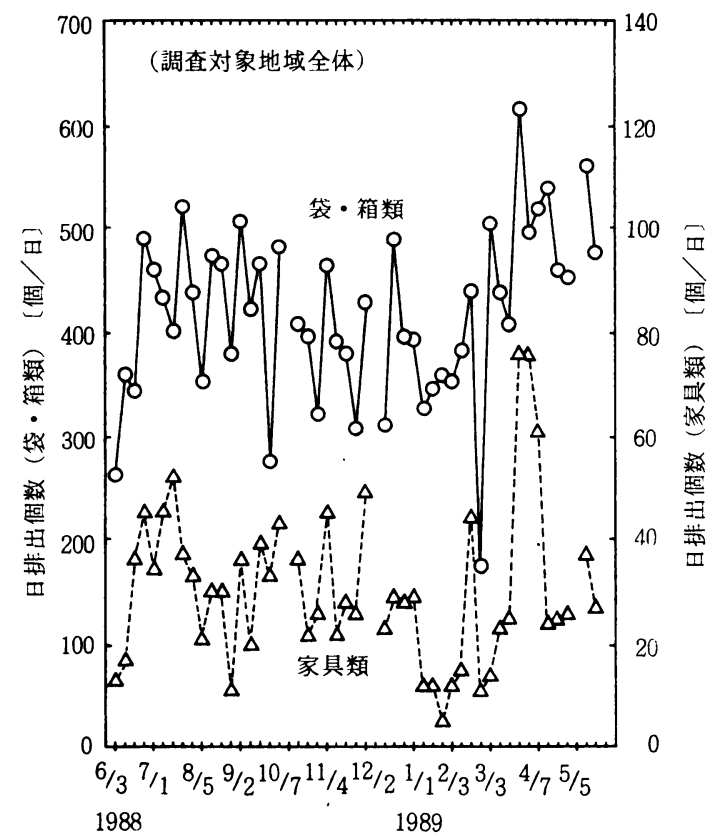

Fig. 1 Daily collected number of bag-box category and furniture category in the whole test area
細かい内訳は, 住居形態別の季節変動の原因を解釈する 際にのみ用い，月平均は月間合計収集個数（または重 量）を月間収集回数（欠測日を除く）で割って求める。

Fig. 2 に, 対象地域内の大分類項目別, 月平均排出 個数を示す。袋・箱類は全体に占める割合が約 $80 \%$ （後述の Table 6 参照）と高いため, 綐軸のスケールを 他の 5 項目の 5 倍にとっている。Fig. 2 より， 1 2 月に少なく $3 \sim 5$ 月に多くなる傾向が，ほぼ全項目に共 通して見られ，春先の清掃による増大であると考えられ る。それに対し，10月は屋外ごみの，また 12 月は屋内 ごみの增大が著しく, それぞれ冬支度のための屋外の片 付け，大掃除による屋内の片付けが原因であると想像さ れる。季節变動の詳細については, 5 で述べる。

\section{4.ビデオ撮影データからの分別ごみ重量推定}

\section{1 組成別重量の測定}

ごみ組成別の個数は, ごみ発生のメカニズムを知るた めの重要な情報であるが, ごみ処理の遂行においては, やはり重量が第一に問題とされる。そこで, ごみ組成別 の重量を測定し, 個数データより大分類項目別の重量を 推定する。

前述のように, 袋・箱類の排出個数は他のものに比較 してきわだって多く, その重量のとり方が全体の重量推 定の精度に及ぼす影響は大きい。特に, 種類の多様さに

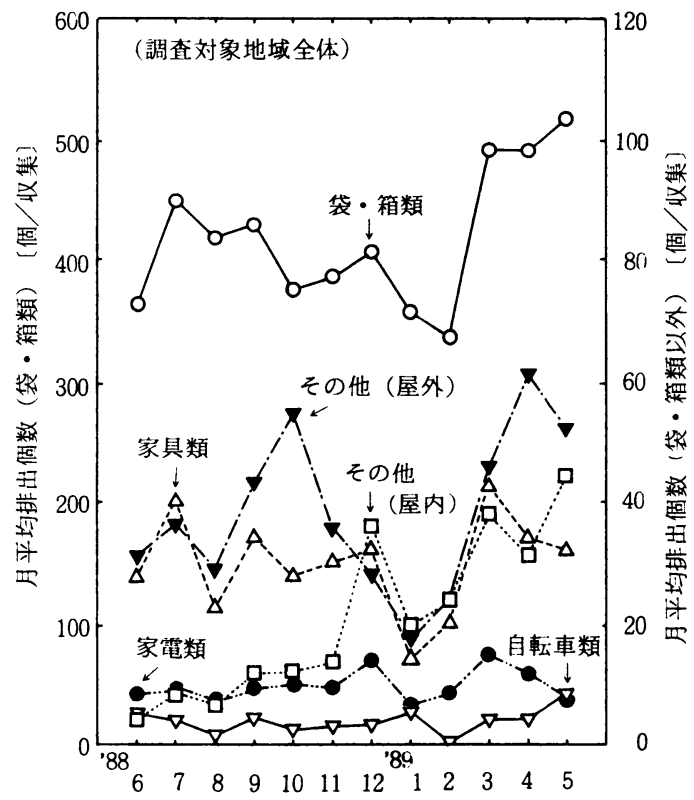

Fig. 2 Seasonal variation of collected amount in number in the whole test area, on monthly average base 
よる重量の幅はあってもそれ自体の重量は変化しない家 具, 家電などと違って，季節により中身が異なり，重量 が変化することも考えられる。そのため，袋・箱類につ いては，単に測定値を平均するだけではなく，季節間の 差の有無を調べた。ビデオ撮影調査地域で撮影と同時に 重量を測定することは困難なので，まず同一時期に異 なった地域で調查を行ない差のないことを確認し，次に 季節間の差を調べた。袋・箱類の中身（組成）の調査は, 行なっていない。

まず昭和 63 年 5 月, 北区内の異なった収集地域にお いて, ステーションに排出されたごみの重量を種類別に 測定した。Table 3 に，袋・箱類の中であ排出個数の 多い 4 種類のあのについての結果をまとめて示す。この 表をもとに，「平均値が等しい」との帰無仮説をたて, 4 日間（それぞれ異なった地区である）の結果をそれぞ れ対にして平均値の差の検定（Welch の方法による） を行なったところ，ポリごみ袋の 23 日と 26 日の組合せ について有意な差が認められた（有意水準 $5 \%$ ）。 5 月 26 日のごみ袋の中には, 土砂の入った $15 \mathrm{~kg}$ 以上のも のが 3 袋含まれていたが，ビデオ撮影調査においてもそ うした重そうなごみ袋が頻度は小さいものの観察されて おり, むしろ 26 日の調查個数の少なさが検定の結果に 影響したと思われる。

次に, 9 月, 1 月にも同様の重量測定を行ない, Table 4 にその結果をまとめる。 5 月の数值は, Table 3 の全サンプルを用いて袋種類別に求めた值である。こ の表をもとに先と同様の検定を行なったところ，スー パーの袋, 段ボール箱のよ゙ちらあ 9 月と 1 月の組合せに ついて，有意な差が認められた。しかし，袋・箱類の重 量を季節ごとに定めるだけの十分な重量測定データがな
いので, Table 4 をさらに合計し, Table 5 に示す平 均重量を用いることにする。

一方，袋・箱類以外のごみ組成についても同時に重量 を測定したが, 重量調查時に排出されていなかった項目 については大学内や個人の家庭内で別に測定した。各項 目のサンプル数は, $2 \sim 3$ 個のものが多い。以上の調査 によって設定したごみ組成別の重量が, Table 2 に示 されている。

\section{2 重量の推定誤差.}

前節のようにして定めた重量データを用い, 排出個数 データから大分類項目別の重量を推定することができる。 通常, ビデオ調查では対象地域のみしか撮影していない が，重量推定の精度をチェックするため，18 日間は収 集車が満載になるまで撮影を続けた。収集されたごみ重 量は, 最終処分場むしくは清掃工場におけるトラックス ケールでの計量により知ることができる。

ビデオ撮影調査による推定重量とトラックスケール計 量値との比較を, Fig. 3 に示す。降雨の有無により差 が見られたので, 降雨のない日と, 収集日前日の午後 9 時以降, 収集日当日までに時間降雨量 $10 \mathrm{~mm} / \mathrm{h}$ 以上を 記録した日を，記号で区別した。降雨を前日からとした のは, 可燃ごみと違って，分別ごみは収集日前日から排 出されていることが多いためである。図より, 降雨のな い収集日については, 計量值に対する推定値の誤差がほ ぼ10\%以内で，よく一致していると言える。ただし， 18 日間のうち 1 日を除いて推定重量は計量値より小さ く, 重量がやや小さ目に推定されている。一方, 降雨が あった収集日の誤差は大きいが，これはカーペット，ふ とん，マットレスなどが雨で需れることや，収集車の投

Table 3 Regional difference in weight of bag-box waste category

\begin{tabular}{|c|c|c|c|c|c|c|c|c|c|c|c|c|}
\hline 調查日 & \multicolumn{3}{|c|}{ ポリごみ袋 } & \multicolumn{3}{|c|}{ スーパーの袋 } & & \multirow{2}{*}{$\begin{array}{l}\text { 袋 } \\
1.90\end{array}$} & \multicolumn{3}{|c|}{ 段ボール箱 } \\
\hline $5 / 11$ (水) & 24 & 3.80 & 4.18 & 48 & 1.44 & 1.16 & 10 & 2.72 & & 25 & 6.47 & 6.43 \\
\hline $5 / 23$ (月） & 33 & 2.84 & 2.89 & 67 & 1.36 & 0.92 & 11 & 2.39 & 1.00 & 32 & 4.38 & 2.07 \\
\hline 5/24（火） & 27 & 3.79 & 1.85 & 64 & 1.40 & 1.24 & 17 & 1.59 & 0.84 & 29 & 4.09 & 3.51 \\
\hline 5/26（木） & 16 & 6.64 & 5.13 & 17 & 1.34 & 0.98 & 3 & 2.63 & 1.31 & 17 & 5.55 & 4.11 \\
\hline
\end{tabular}

（左からサンプル数, 平均重量 $[\mathrm{kg}]$, 標準偏差 $[\mathrm{kg}]$ )

Table 4 Seasonal difference in weight of bag-box waste category

\begin{tabular}{|c|c|c|c|c|c|c|c|c|c|c|c|c|}
\hline 調查日 & \multicolumn{3}{|c|}{ ポリごみ袋 } & \multicolumn{3}{|c|}{ スーパーの袋 } & \multicolumn{2}{|c|}{ 紙 } & \multirow{2}{*}{$\frac{\text { 袋 }}{1.29}$} & \multicolumn{3}{|c|}{ 段ボール箱 } \\
\hline 5 月 & 100 & 3.93 & 3.64 & 196 & 1.39 & 1.09 & 41 & 2.16 & & 103 & 5.00 & 4.24 \\
\hline 9 月 & 51 & 3.17 & 1.50 & 175 & 1.19 & 0.87 & 34 & 2.04 & 1.14 & 46 & 3.91 & 3.22 \\
\hline 1 月 & 43 & 3.63 & 1.71 & 159 & 1.52 & 1.01 & 25 & 2.17 & 1.34 & 60 & 5.56 & 3.81 \\
\hline
\end{tabular}

（左からサンプル数, 平均重量 $[\mathrm{kg}]$, 標準偏差 $[\mathrm{kg}]$ ) 


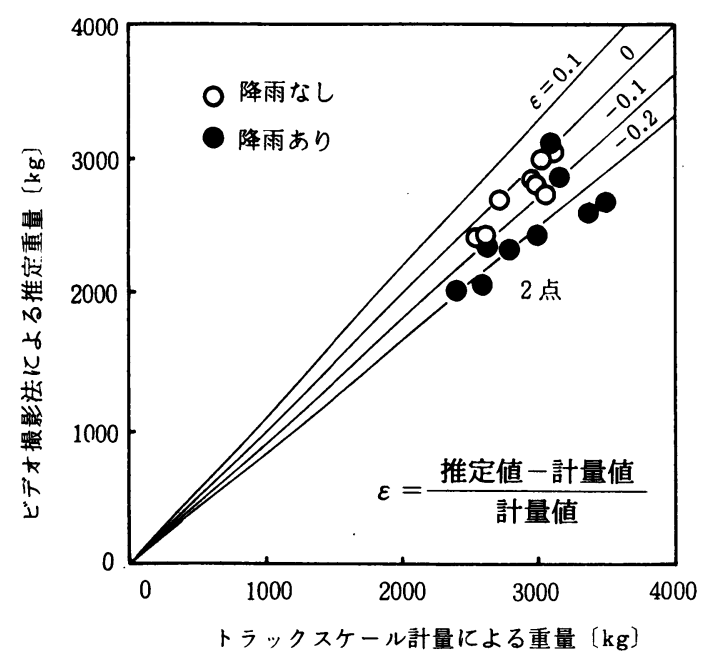

Fig. 3 Estimation error in the amount collected in one truck, comparing with weighing scale measurement

入口に水がたまるなどの理由によるものと考えられる。 降雨があった日の平均推定誤差はー $14.5 \%$ であり, 非 降雨日の平均誤差 $(-4.5 \%)$ との差から, 降雨による 水分のため, $10 \%$ 程度収集量が増加すると推測できる。

\section{3 対象地域内のごみ重量変動}

Fig. 4 に，対象地域全体に対する大分類項目別推定 重量の年間変動を示す。図は, 個数表示した Fig. 2 に 対応するむので, 月平均排出重量（=月間合計収集重量 /月間収集回数，欠測日を除く）を示しており，まず Table 2 の重量データを用いて個数を重量に直し，そ の後はFig. 1, Fig. 2 を得たのと同じ手順によってい

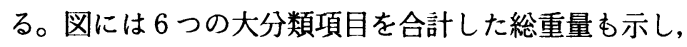
袋・箱類, および総重量の縌軸のスケールは, 他の項目 の 2 倍とした。

Fig. 2 と較べて, 項目別の変動傾向が大きく異なる ところはないが, 組成別の重量の違いのため, 袋・箱類 以外の占める割合が高くなっている。Table 6 の上段 に, 対象地域全体の大分類項目別組成割合を示すとおり, 家具類と家電類を合わせて約 4 分の 1 を占め, 袋・箱類 の割合は $66.2 \%$ である。昭和 63 年 8 月に, 札幌市清掃 部が分別ごみの組成分析調査（サンプル量 18.9 トン） を行っているが6)，粗大ごみとそれ以外（ガラス，金属， プラスチックなどに分類）とに分け，粗大ごみの割合は $37.6 \%$ であった。今回の調宜で,「粗大ごみが袋や箱に 入っていず，袋や箱に入っていないあのがすべて粗大ご みである」とは言えないが，仮にそう考えると粗大ごみ の割合は $33.8 \%$ となり，市の調査結果とほぼ一致する。

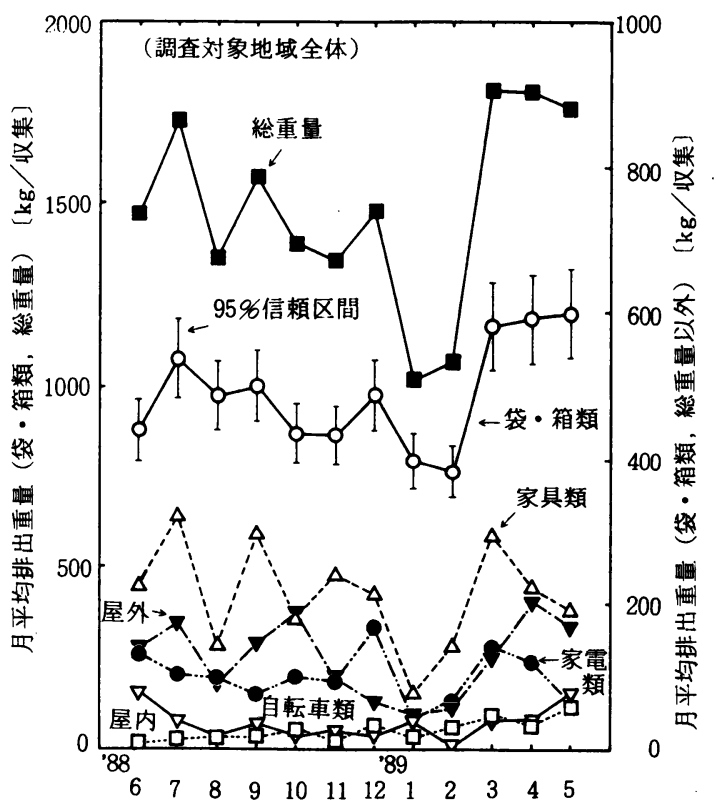

Fig. 4 Seasonal variation of collected amount in weight (estimated) in the whole test area, on monthly average base

Table 5 Summary of weighing survey of bag-box waste category

\begin{tabular}{|c|c|c|c|}
\hline & 調查個数 & 平均重量 [kg] & 標準偏差 [kg] \\
\hline ポリごみ袋 & 194 & 3.67 & 2.85 \\
\hline スーパーの袋 & 530 & 1.37 & 1.01 \\
\hline 紙 & 100 & 2.12 & 1.24 \\
\hline 段ボール箱 & 209 & 4.92 & 3.94 \\
\hline 米 & 24 & 1.93 & 0.97 \\
\hline 肥 料 垡 & 8 & 5.27 & 1.85 \\
\hline
\end{tabular}

Fig. 4 の総重量の季節変化を, 調査地域を含む北区 金曜収集地域の収集量のそれと比較したのが Fig. 5 で ある。どちらも月平均の値で（ただし調查欠測のある月 は日数が異なる), 図中に年平均（=月平均の合計/12） の収集量を示すように，調查対象地域はごみ量にして金 曜収集地域全体のおよそ 30 分の 1 にあたる。比較を容 易にするため，それぞれ年平均に対する比で表している。 刚より, 両者の変動パターンはよく似ている。

Fig. 4 には，袋・箱類の重量について， Table 5 よ り種類別重量の $95 \%$ 信頼区間を求め, それぞれの上限 （あるいは下限）をとって算出した信頼区間を示してい る。区間幅は, Table 5 の標準偏差の大きさを反映し て広く, 統計的に明らかなのは $3 \sim 5$ 月の増大のみであ 


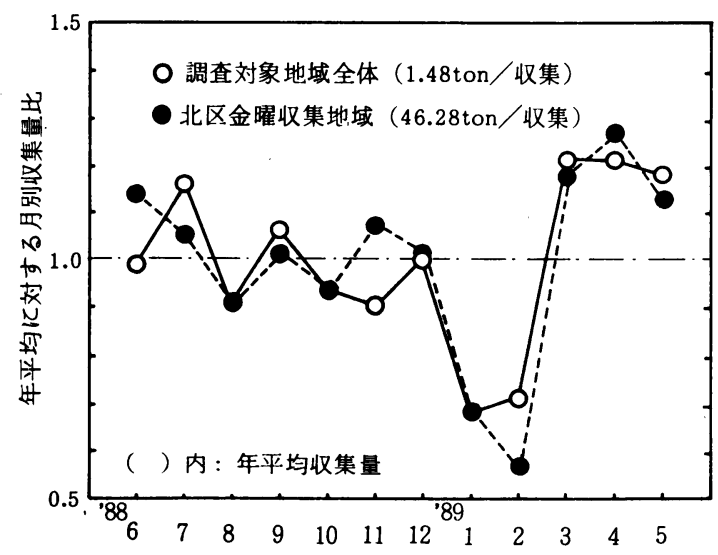

Fig.5 Estimated collection weight in the test area, and collected amount (actually weighed) in the Friday-collection area in Kita-ku, both in the ratio of monthly average to the yearly average

る。しかし, Fig. 5 より，本方法による調查地域の推 定重量変動が調查地域を含む広い地域での収集量のそれ とよく一致していること（ただし，一致の度合を重量推 定精度の尺度とするには，地域ごとのごみ発生特性が同 一かどうかを調べる必要がある), および Fig. 3 で示さ れた重量推定誤差の小ささから, 重量でごみ全体の 3 分 の 2 を占める袋・箱類の重量推定は，季節による重量の 違いが示唆されたにあかかわらず， Table 5 の平均重 量を用いることでうまく行われていると思われる。

\section{5、住居形態別のごみ発生特性}

調查対象地域は，2で述べたように，一户建て， ア パート，集合住宅などが混在しているが，それぞれの住 居形態に特有なごみ質, 固有なごみの発生パターンがあ るのではないかと思われる。そこで, 最新の住宅地目及 び調查時の視察を参考に, 周囲の住居形態が明確なス
テーションを抽出し， Table 6 に示す 3 つのグループ に分けた。表中「一戸建て」とは，一戸建て住宅のみか らごみが排出されるステーションの意であり,「アパー 卜」と分類したステーションの中には, 一户建てからの ごみ排出があっても，その量がアパートからのごみ量に 較べて十分小さい場合も含んでいる。アパートには独身 者が多く住んでいると思われる。また，対象地域内に集 合住宅はいくつかあるが, 最む入居世帯数の多い高層ア パートを選んだ。Table 6 に示すように, 各ステー ション群から排出されるごみ量はほぼ同じであり，年平 均値から算出した個数，重量の組成百分率も同時に示す。

Fig. 6，7，8にそれぞれアパート，一戸建て，高 層アパートの月別個数变動を示す。重量で表示すると項 目別の重量差が大きいため（例えば大型の冷蔵庫は 60 $\mathrm{kg}$ 程度ある), 重い屯のの排出の有無に大きく影響され てしまう。そのため,ごみ排出特性を見るには個数基準 が好ましいと判断した。以下では, 大分類項目中の細か な内訳も調べ, 各住居形態のごみ発生構造を明らかにす る。

まずアパートについて見ると（Fig. 6)，9月，3月 に家具類が多く，季節の変わり目に部屋の中の片づけが 行われたことがうかがわれる。この時期には袋・箱類す 増大しており, 日単位のごみ量を調べてみると, 9 月末, 3 月末に排出が集中していた。また，9〜10月，3〜 5 月の屋外ごみの増大は, 屋内にあったと思われる木の 板等も屋外ごみと分類してしまったためで, 家具類, 袋・箱類と同様, 片づけにより発生したと考えられる。 12 月の家具類の増大は年末の買い替え, 大掃除による と思われる。

次に一戸建て（Fig. 7）について見ると，Fig. 6 と は排出の傾向が異なっていることがわかる。すなわち, 袋・箱類に見られるように $3 \sim 5$ 月に増大し，以後 9 月 までほぼ一定した排出が続いている。屋外ごみも，8月 に減少することを除けば，同様に春から秋までごみ排出

Table 6 Description of sub-test areas and waste composition

\begin{tabular}{|c|c|c|c|c|c|c|c|c|}
\hline \multirow{2}{*}{$\begin{array}{l}\text { ステーション } \\
\text { の 分 類 }\end{array}$} & \multirow{2}{*}{ 概 要 } & \multirow{2}{*}{$\begin{array}{l}\text { 年平均ごみ量 } \\
\text { 上: [個/収集] } \\
\text { 下: [kg/収集 }]\end{array}$} & \multicolumn{6}{|c|}{ 大分類項目別組成百分率 [\%] 上：個数 下：(重量) } \\
\hline & & & 袋・箱類 & 家電類 & 家具類 & 自転車類 & 屋内 & 屋外 \\
\hline 対象地域全体 & 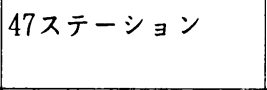 & $\begin{array}{c}522.5 \\
(1479.5)\end{array}$ & $\begin{array}{c}80.2 \\
(66.2)\end{array}$ & $\begin{array}{c}1.9 \\
(6.8)\end{array}$ & $\begin{array}{c}5.7 \\
(14.2)\end{array}$ & $\begin{array}{c}0.8 \\
(2.5)\end{array}$ & $\begin{array}{c}4.0 \\
(1.8)\end{array}$ & $\begin{array}{l}7.4 \\
(8.5)\end{array}$ \\
\hline $\begin{array}{l}\text { アパ- }- \text { ハ } \\
(2 \sim 3 \text { 階建て })\end{array}$ & $\begin{array}{l}8 \text { ステーション } \\
\text { 独身者が多い }\end{array}$ & $\begin{array}{c}89.1 \\
(255.2)\end{array}$ & $\begin{array}{c}82.6 \\
(66.1)\end{array}$ & $\begin{array}{c}1.8 \\
(6.8)\end{array}$ & $\begin{array}{c}6.5 \\
(15.7)\end{array}$ & $\begin{array}{l}1.1 \\
(3.0)\end{array}$ & $\begin{array}{c}2.6 \\
(1.4)\end{array}$ & $\begin{array}{l}5.4 \\
(7.1)\end{array}$ \\
\hline 一戸建 て & $\begin{array}{l}13 \text { ステーション } \\
\text { 約 } 60 \text { 軒 }\end{array}$ & $\begin{array}{c}68.8 \\
(204.1)\end{array}$ & $\begin{array}{c}82.9 \\
(65.5)\end{array}$ & $\begin{array}{l}2.0 \\
(9.6)\end{array}$ & $\begin{array}{l}3.8 \\
(8.2)\end{array}$ & $\begin{array}{c}0.8 \\
(3.9)\end{array}$ & $\begin{array}{c}2.7 \\
(1.5)\end{array}$ & $\begin{array}{c}7.8 \\
(11.3)\end{array}$ \\
\hline $\begin{array}{c}\text { 高層アパート } \\
(11 \text { 階建て) }\end{array}$ & $\begin{array}{l}\text { 住宅公団 1ステーション } \\
\text { 1DK-40, 2DK-130世带 }\end{array}$ & $\begin{array}{c}77.2 \\
(196.2)\end{array}$ & $\begin{array}{c}76.7 \\
(66.5)\end{array}$ & $\begin{array}{l}2.8 \\
(6.9)\end{array}$ & $\begin{array}{c}6.9 \\
(16.1)\end{array}$ & $\begin{array}{c}0.3 \\
(0.8)\end{array}$ & $\begin{array}{c}5.8 \\
(2.2)\end{array}$ & $\begin{array}{l}7.6 \\
(7.5)\end{array}$ \\
\hline
\end{tabular}




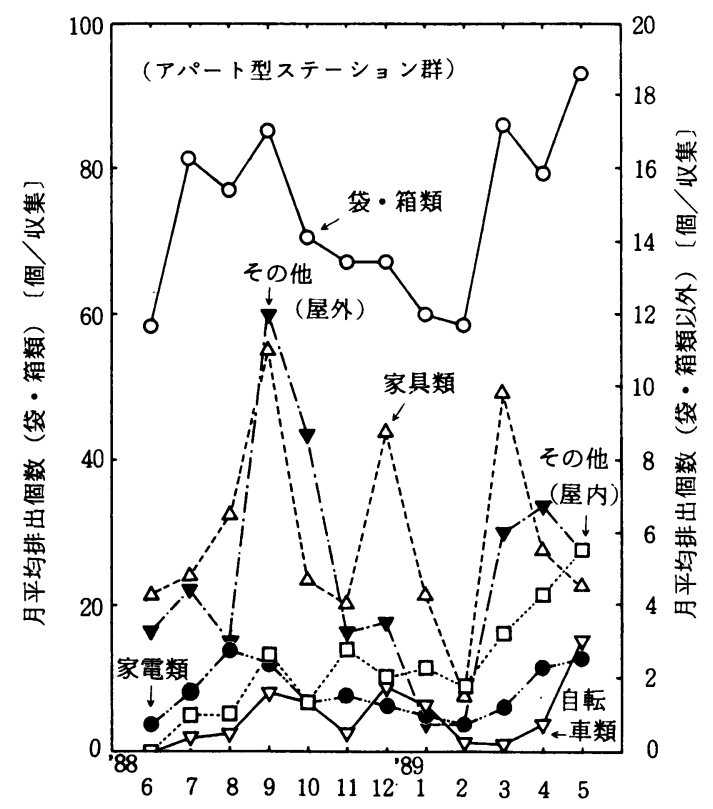

Fig. 6 Seasonal variation of collected amount in number in 2 to 3-story apartment house category, on monthly average base

が継続されている。一戸建てからの屋外ごみは，室内か らの木の板などのほかに, 庭木が $1 / 2 \sim 1 / 3$ を占め ており，庭の片づけによるごみの割合が高い。Fig. 6 と比較して, もう一つの大きな相異は家具類の少なさで, 12 月にも増大していない。これはアパートから排出さ れていたのが，カラーボックス，衣装ケース，薄手の カーペットなどであるのに対し，一戸建てでは，より耐 用年数の長いものが使用されていること, 収納スペース が十分あり室内を整理する必要が少ない（あるいは整理 をしてあ排出する必要が少ない）ことが原因ではないか と思われる。

一方, 高層アパート（Fig. 8） のごみ排出傾向は前 2 者とはかなり異なっている。つまり，アパート，一戸 建てではごみの少ない 2 月, 10 ～11 月に逆にごみが増 えている。Fig. 6 で見られた 9 月， 3 月のごみ量の ピークは, それぞれ冬を迎える（寒くなる）前, 春の暖 かくなってからの清掃行動によると考えられるが，この 高層アパートは全室集中暖房であり, 清掃行動が外気温 の低さに左右されなくなる。このため，秋の片づけが 10 月末から徐々に始められ，2月中旬から早くも春の 片づけが始まっていると, 日単位のデータから推測でき る。家具類の内容はアパートのそれと大差なく，12月 の家電の著しい増大は照明器具, 掃除機, ガスレンジな よ゙が多いためである。

以上のように，住居形態によりごみ排出パターンに特

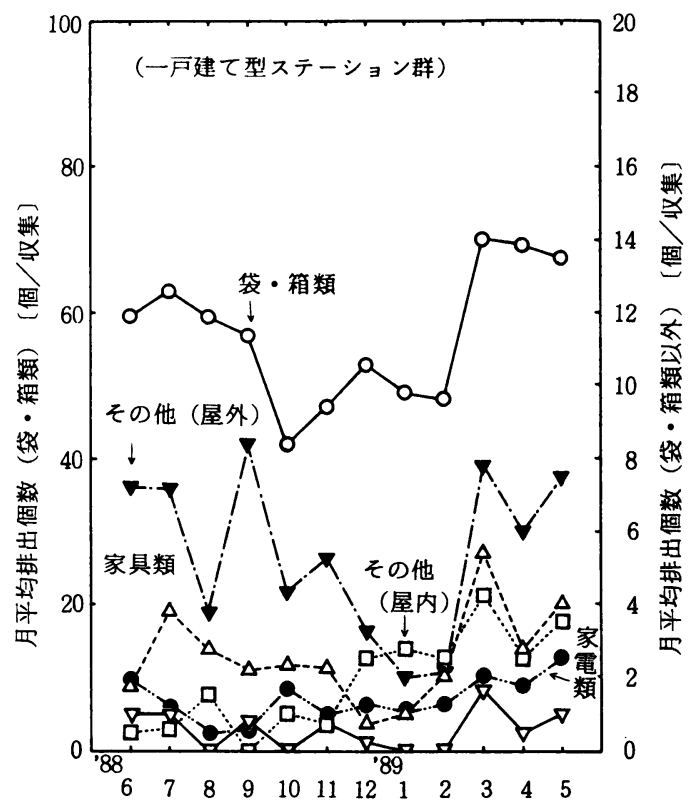

Fig. 7 Seasonal variation of collected amount in number in single-family-dwelling category, on monthly average base

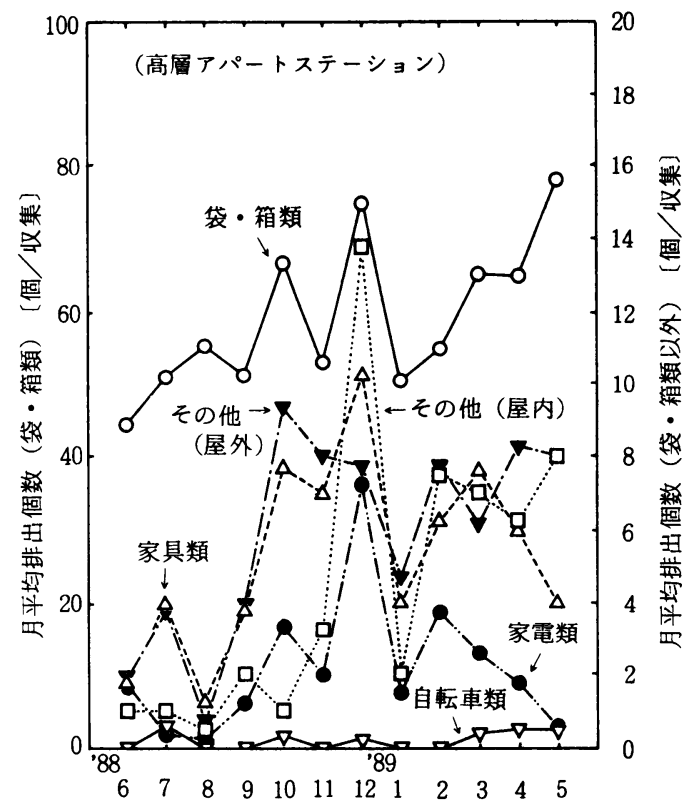

Fig. 8 Seasonal variation of collected amount in number in a big apartment complex, on monthly average base

徵が見られる。しかし, 調查地域内にある市営住宅, 警 察公宿, 共済住宅はいずれも5階建てアパートであるが, それぞれに異なった変動パターンが見られ（図は省略）, 上記の結果が札幌市におけるそれぞれの住居形態の排出 
特性を代表するとは，断定しがたい。また，ごみ量は住 民一人あたりの量（原単位）で比較すべきであるが，今 回はステーション群別の人口を把握していない。この節 での議論む, 原単位ベースで比較すると違った解釈が生 まれる可能性がある。

\section{6. おわりに}

本論文の内容, 結論をまとめると, 以下のようになる。 1）分別ごみ（不然ごみと粗大ごみ）の質・量の季節 変動を調べるため, ビデオ調査法を提案し, 調査地域を 定めて一年間，調查を行なった。

2) 従来の手作業による組成分析と較べ，ビデオ調査 法によると, 人数, 時間, 分析のための場所が, 大幅に 節約できる。また，写真やテープレコーダーを用いる調 查法と較べても, 収集時点で行なう調查のため排出全量 を 1 個ずつ見ることができ，画像・音声の同時記録であ る点で優れている。

3 ）ごみの種類は数多いため, 大きく 6 つの項目に分 類し，大分類項目別個数の季節変動パターンを明らかに した。袋・箱類の割合が多く，全体の約 $80 \%$ を占めて いる。

4 ）個数のみの計測という短所を補うため，ごみ組成 別の重量測定調査を行ない，重量を推定した。収集車一 台分の推定重量をトラックスケールによる計量値と比較 し，十分な精度が確かめられた。また，降雨により $10 \%$ 程度重量が增加している。

5 ) 住居形態別個数の年間変動パターンを調べ， 3 〜 5 月， 9 月末， 12 月の増大が認められた。これらは清 掃（片付け）によるごみ排出と考えられるが，住居形態 により増大の程度が異なり，また気温の変化が清掃行動 の時期に影響していることがわかった。

なお，本論文の一部は，第 40 回発対協全国大会（pp. 91 - 96, 1989)，第 45 回土木学会年次講演会（第 2 部，pp. 962- 963 , 1990）で発表した。最後に，調査にご協力いただいた机幌市清 掃部の方々に感謝致します。

\section{参考文献}

1）松藤敏彦，神山桂一，罒中信寿：都市ごみ収集军の季 節変動パターンに関する研究，卜來学会論文集，第 393 岇/ II - 9，pp. $201-208$ (1988)

2 ）松藤敏彦, 神山桂；田中信寿：都市ごみ収集军の日 変動と住民のごみ排出行動に関する考察, 衛生 [学研究 論文集, Vol. 24, pp. 209-216（1988）

3 ）松藤敏彦，且中信寿，松尾孝之，神山桂--：可燃ごみ の収集原単位におよぼす事業系ごみ混入の影響, 都市清 掃, 第 42 巻第 169 号, pp. 43-50 (1989)

4) 松尾孝之, 松藤敏彦, 神山桂一, 田中信寿：ごみス テーションの写真撮影による可燃ごみ排出量調査, 第 39 回廃棄物処理対策全国協議会全国大会, pp. 112-115 (1988)

5 ）松尾孝之, 松藤敏彦, 田中信寿, 神山桂一, 飯田純 : ごみステーションにおける可燃ごみ排出量の簡易調查法 について, 第 44 回土木学会年次学術講演会 (第 II 部), pp. 960 - 961 (1989)

6 ）小山義夫： 分別収集ごみ収集回数の増加に伴う排出状 況の実態調查, 都市清掃, 第 42 巻第 170 号, pp. $245-$ 241 (1989) 


\title{
Survey of Noncombustible and Bulky Waste Generation by the Use of Video Recording
}

\author{
Toshihiko Matsuto, Nobutoshi Tanaka, Takayuki Matsuo, \\ Masanori KobarI* and Keiichi Koyama
}

(Dept. of Sanitary \& Environmental Engineering, Hokkaido University

*Hitachi Ltd.)

\begin{abstract}
Since information on the quantity and quality of waste is crucially important in the waste management planning, efficient survey methods are required. The authors employed a VCR (video cassette recorder) in a survey of noncombustible and bulky waste. The survey was carried out in a specified residential test area in Sapporo over a period of one year.

Waste items are categorized into six groups. In the survey the number of disposed-of waste items are counted, so a separate survey was also carried out to determine the weight of every item. For determination of amounts collected, the margin of error in a truck is less than $10 \%$.

The seasonal generation pattern is discussed for three types of residence. Though increases of waste in springtime, autumn, and December are seen in all three, their timing and magnitude differ.
\end{abstract}

Key words : video recording, noncombustible and bulky waste, waste generation, seasonal variation, residence type 